\title{
CHEMOSPHERE
}

\section{Levels and pattern of volatile organic nitrates and halocarbons in the air at Neumayer Station $\left(70^{\circ} \mathrm{S}\right)$, Antarctic}

\author{
Ralf Fischer ${ }^{\mathrm{a}, 1}$, Rolf Weller ${ }^{\mathrm{b}}$, Hans-Werner Jacobi ${ }^{\mathrm{b}, 2}$, \\ Karlheinz Ballschmiter ${ }^{\mathrm{a}, *}$ \\ a Department of Analytical and Environmental Chemistry, University of Ulm, Albert-Einstein-Allee 11, D-89081 Ulm, Germany \\ b Alfred-Wegener-Institute for Polar and Marine Research, Am Handelshafen 12 D-27570 Bremerhaven, Germany
}

Received 13 February 2001; received in revised form 14 February 2002; accepted 28 February 2002

\begin{abstract}
Levels and patterns of $\mathrm{C} 1-\mathrm{C} 4 / \mathrm{C} 9$ organic nitrates were measured for the first time in Antarctica. The sampling was done by adsorptive enrichment on Tenax TA followed by thermodesorption cold-trap high resolution capillary gas chromatography with electron capture detection. 2-70 1 air on-column have been analyzed this way. C1-C9 alkyl mononitrates, $\mathrm{C} 2-\mathrm{C} 4$ alkyl dinitrates, $\mathrm{C} 2-\mathrm{C} 4$ hydroxy alkyl nitrates, and halocarbons could be identified in air samples collected near the German Neumayer Research Station, Antarctica, in February 1999. Volatile biogenic and anthropogenic halocarbons were used to assess the origin of the air parcels analyzed. The average concentration measured for $\sum \mathrm{C} 2-\mathrm{C} 6$ alkyl nitrates was in the range of $9.2 \pm 1.8 \mathrm{ppt}(\mathrm{v})$, while the sum of the mixing ratios of six $\mathrm{C} 2-\mathrm{C} 4$ hydroxy alkyl nitrates was in the range of $1.1 \pm 0.2 \mathrm{ppt}(\mathrm{v})$. Moreover, $\mathrm{C} 2-\mathrm{C} 4$ alkyl dinitrates were found at levels near the detection limit of 0.1-0.5 ppt(v). The concentrations of organic nitrates found in Antarctic air represent ultimate baseline levels due to chemical and physical loss processes during long-range transport in the air. The South Atlantic and the Antarctic Ocean as a general secondary source for organic nitrates in terms of an air/sea exchange equilibrium has to be evaluated yet, but it seems logical. Our results confirm the common assumption that there are no biogenic marine sources of $\mathrm{C} 2-\mathrm{C} 9$ organonitrates. We have found a level of $>80 \mathrm{ppt}(\mathrm{v})$ for methyl nitrate. This level if it can be confirmed in a systematic survey requires a strong biogenic source of methyl nitrate in the Antarctic Ocean.
\end{abstract}

(c) 2002 Elsevier Science Ltd. All rights reserved.

Keywords: Alkyl mononitrates; Methyl nitrate; Hydroxy alkyl nitrates; Alkyl dinitrates; Air; Antarctica; Thermal desorption; Capillary gas chromatography; Baseline levels; Long-range transport

\footnotetext{
${ }^{*}$ Corresponding author. Tel.: +49-731-502-2750; fax: $+49-$ 731-502-2763.

E-mail address: karlheinz.ballschmiter@chemie.uni-ulm.de (K. Ballschmiter).

${ }^{1}$ Present address: Dr. Th. Böhme KG, Isardamm 79-83, D82538 Geretsried.

${ }^{2}$ Present address: Department of Hydrology and Water Research, 1133 E. North Campus Dr., University of Arizona, Tucson, AZ 85721-0011, USA.
}

\section{Introduction}

The troposphere has to be considered in general as an oxidative medium with the tendency for species to be converted to a more oxidized state. The results of the light induced photochemistry and oxidation chemistry of hydrocarbons in air depend on the levels of the reaction of starting radicals such as $\mathrm{OH}$, or $\mathrm{NO}_{3}$, and on the levels of trace gases like odd-nitrogen $\mathrm{NO}_{y}$, (particularly $\mathrm{NO}_{x}\left(\mathrm{NO}+\mathrm{NO}_{2}\right)$ as main part), ozone, and organosulfur compounds (Atlas et al., 1992a,b; Carroll et al., 1992; Barrie et al., 1994; Kondo et al., 1997; Platt 
and Le Bras, 1997). As a result of combustion emissions, levels of $\mathrm{NO}_{x}$ greatly enhanced over those in the background troposphere can be found in urban and densely inhabited continental areas. $\mathrm{NO}_{x}$ is the key in the organonitrogen chemistry of the urban troposphere. When $\mathrm{NO}$ and $\mathrm{NO}_{2}$ are present in sunlight, ozone formation occurs as a result of photolysis of $\mathrm{NO}_{2}$ at wavelength $\lambda<424 \mathrm{~nm}$.

$$
\begin{aligned}
& \mathrm{NO}_{2}+h v \rightarrow \mathrm{NO}+\mathrm{O}\left({ }^{3} \mathrm{P}\right) \\
& \mathrm{O}\left({ }^{3} \mathrm{P}\right)+\mathrm{O}_{2}+\mathrm{M} \rightarrow \mathrm{O}_{3}+\mathrm{M}^{\ddagger}
\end{aligned}
$$

On the other hand, ozone reacts with NO to regenerate $\mathrm{NO}_{2}$.

$$
\mathrm{O}_{3}+\mathrm{NO} \rightarrow \mathrm{NO}_{2}+\mathrm{O}_{2}
$$

Therefore the steady-state ozone concentration is approximated by Eq. (4)

$\left[\mathrm{O}_{3}\right]=\frac{J_{1}\left[\mathrm{NO}_{2}\right]}{k_{3}[\mathrm{NO}]}$

Expression (4) is named the photostationary state relation. The ozone concentration is in a first approximation proportional to the $\mathrm{NO}_{2} / \mathrm{NO}$ ratio, which means high $\mathrm{NO}_{2}$ levels lead to high ozone concentrations. Conversion of $\mathrm{NO}$ to $\mathrm{NO}_{2}$ by $\mathrm{HO}_{2}$ or peroxyalkyl radicals (7a) will lead to increases in ozone and deviation from Eq. (4).

Members of the $\mathrm{NO}_{y}$ pool are also involved in these processes by increasing or reducing $\mathrm{NO}_{x}$ levels in the air. Alkyl nitrates as parts of the $\mathrm{NO}_{y}$ pool are therefore of potential interest.

Alkyl nitrates besides being compounds of the atmospheric chemistry are used as propellants, and explosives (Köhler and Meyer, 1995). Together with the alkyl nitrites they are a group of potent pharmaceuticals, e.g. isosorbid dinitrate is a powerful vasodilator (Ahlner et al., 1991). None of the technical and pharmaceutical uses leads however to a general environmental contamination. Local contaminations by explosives may occur.

The source of alkyl nitrates in the troposphere is the conversion of hydrocarbons (Fraser et al., 1997). $\mathrm{OH} / \mathrm{O}_{2}$ (5a) or $\mathrm{NO}_{3} / \mathrm{O}_{2}(5 \mathrm{~b})$ attack on an aliphatic carbonhydrogen or an olefinic $\mathrm{C}=\mathrm{C}$ bond forms peroxyalkyl radicals $\mathrm{RO}_{2}$ (6). They are also formed by a thermolysis/ $\mathrm{O}_{2}$ reaction (5c) of long chain alkoxy radicals and by the photolysis (5d) of carbonyl compounds followed by the addition of $\mathrm{O}_{2}$. The reaction of peroxyalkyl radicals with NO leads to nitrogen dioxide and alkoxy radicalsfinally stabilizing as carbonyl compounds (7a) and (7b) - or in a side reaction to alkyl nitrates (reactions (7c)) (Atkinson et al., 1982; Finlayson-Pitts and Pitts, 1986; Atkinson, 1990; Seinfeld and Pandis, 1998).
- Formation of alkyl radicals (initial step):

$$
\begin{aligned}
& \mathrm{RH}+\mathrm{OH}^{\cdot} \rightarrow \mathrm{R}^{\cdot}+\mathrm{H}_{2} \mathrm{O} \\
& \mathrm{RH}+\mathrm{NO}_{3}^{\cdot} \rightarrow \mathrm{R}^{\cdot}+\mathrm{HNO}_{3} \\
& \mathrm{R}^{\prime} \mathrm{RHC}-\mathrm{O}^{\cdot}+\Delta \rightarrow \mathrm{R}^{\cdot}+\mathrm{R}^{\prime} \mathrm{HC}=\mathrm{O} \\
& \mathrm{R}^{\prime}(\mathrm{C}=\mathrm{O}) \mathrm{R}+h v \rightarrow \mathrm{R}^{\cdot}+\mathrm{R}^{\prime} \mathrm{C}=\mathrm{O}
\end{aligned}
$$

- Formation of peroxyalkyl radicals:

$$
\mathrm{R} \cdot+\mathrm{O}_{2}(+\mathrm{M}) \rightarrow \mathrm{RO}_{2}^{\cdot}\left(+\mathrm{M}^{\ddagger}\right)
$$

- Formation of stable products:

$$
\begin{aligned}
& \mathrm{RO}_{2}^{+}+\mathrm{NO} \rightarrow \mathrm{RO}+\mathrm{NO}_{2} \\
& \mathrm{RO}^{*}+\mathrm{O}_{2} \rightarrow \mathrm{R}_{1} \mathrm{R}_{2} \mathrm{CO}+\mathrm{HO}_{2} \\
& \mathrm{RO}_{2}^{+}+\mathrm{NO}(+\mathrm{M}) \rightarrow\left(\mathrm{RO}_{2} \mathrm{NO}\right)\left(+\mathrm{M}^{\ddagger}\right) \rightarrow \mathrm{RONO}_{2}
\end{aligned}
$$

This reaction scheme may repeat itself with alkyl nitrates leading finally to carbonyl alkyl nitrates or to non-vicinal alkyl dinitrates.

The reaction of alkenes with either $\mathrm{OH}$ during daytime or with $\mathrm{NO}_{3}$ during nighttime in the presence of $\mathrm{NO}_{x}$ leads to the formation of multifunctional organic nitrates like hydroxy alkyl nitrates or alkyl dinitrates (O'Brien et al., 1995; O'Brien et al., 1997; Kastler and Ballschmiter, 1998; Kastler and Ballschmiter, 1999). Moreover, organic nitrates formed by the reaction of isoprene have recently been reported (Werner et al., 1999). A detailed summary of the reaction schemes leading to alkyl nitrates is given by Roberts (Roberts, 1990).

The yield of alkyl nitrates in the branching of the reaction of a peroxyalkyl radical with $\mathrm{NO}(7 \mathrm{c})$ increases from $<0.014$ for ethane to 0.33 for octane. Thus a wide range of homologues and isomeric alkyl nitrates is expected in the atmosphere. The decreasing concentrations of long-chain alkanes are partly offset by the increased yields of alkyl nitrate formation (Atkinson et al., 1982; Schneider et al., 1998a).

While for alkyl mononitrates $\leqslant \mathrm{C} 5$ the dominant loss process is photolysis (8) (Clemitshaw et al., 1997), alkyl nitrates with more than five $\mathrm{C}$-atoms and multifunctional alkyl nitrates are mainly degraded by $\mathrm{OH}$ radicals (9) (Talukdar et al., 1997).

- Atmospheric chemistry of alkyl nitrates

$$
\begin{aligned}
& \mathrm{RONO}_{2}+h v \rightarrow \mathrm{RO}+\mathrm{NO}_{2} \\
& \mathrm{RONO}_{2}+\mathrm{OH}^{\cdot} \\
& \quad \rightarrow \text { multifunctional nitrates, polar products }
\end{aligned}
$$

In continental air alkyl nitrates contribute $2 \%$ to the $\mathrm{NO}_{y}$ budget, increasing up to $15 \%$ for marine air (Atlas et al., 1992a,b). They are a sink of the $\mathrm{NO}_{y}$ pool par- 
ticularly during polar winters. Thus, in arctic air masses the alkyl nitrates can enrich up to $20 \%$ of the total $\mathrm{NO}_{y}$ budget (Bottenheim et al., 1993). Photodegradation of alkyl nitrates results in the formation of $\mathrm{NO}_{x}$. They can act as an important $\mathrm{NO}_{x}$ source in the polar regions with highest release rates of $\mathrm{NO}_{x}$ during polar sunrise.

Since the first measurements of alkyl nitrates in the marine atmosphere 1988 by Atlas (Atlas, 1988), this class of compounds found increasing interest. Several studies took place in the USA, Canada and Germany. Moreover field campaigns took place in the Pacific air (equatorial and Hawaiian region) and the Atlantic air on board RV "Meteor" (Schneider and Ballschmiter, 1999) and RV "Polarstern" (Fischer et al., 2000). In spite of increasing activities in this field of atmospheric chemistry the number of studies in polar regions is limited.

Concentrations in the low ppt(v) range were found for the North Pacific air by Atlas (Atlas et al., 1992a,b; Atlas et al., 1993). Roberts measured concentrations of $14 \pm 8.3 \mathrm{ppt}(\mathrm{v})$ for $\sum \mathrm{C} 1-\mathrm{C} 4$ alkyl nitrates at Chebogue Point, Nova Scotia (Roberts et al., 1998). de Kock found mean concentrations of $17.5 \pm 8.4 \mathrm{ppt}(\mathrm{v})$ for $\mathrm{C} 3-$ C5 alkyl nitrates at the South African southeast coast (de Kock and Anderson, 1994). More recently Schneider reported levels of 3-8 ppt(v) for $\sum \mathrm{C} 3-\mathrm{C} 5$ alkyl nitrates for the South Atlantic air (Schneider, 1998a,b; Schneider and Ballschmiter, 1999). Fischer reported a mean concentration of $1.7 \mathrm{ppt}(\mathrm{v})$ for $\sum \mathrm{C} 4+\mathrm{C} 5$ alkyl nitrates for the North Atlantic air and $1.3 \mathrm{ppt}(\mathrm{v})$ for $\sum \mathrm{C} 4+\mathrm{C} 5$ for the South Atlantic air (Fischer, 1999; Fischer et al., 2000). Fischer gives a global overview on the levels of short chain alkyl nitrates at different continental and marine sampling sites (Fischer and Ballschmiter, 2001).

O'Brien reported 1995 for the first time the occurrence of four alkyl hydroxy nitrates and one alkyl dinitrate (O'Brien et al., 1995; O'Brien et al., 1997). Recently additional hydroxy alkyl nitrates and 30 alkyl dinitrates were identified in urban air (Kastler and Ballschmiter, 1998; Kastler and Ballschmiter, 1999; Fischer et al., 2000).

We believe to be the first to present in this work levels and patterns of higher organic nitrates in the lower troposphere of the Antarctic. Furthermore we compare the occurrence of alkyl nitrates with the levels of halocarbons as atmospheric markers. A comparison with values obtained in South Atlantic air places the Antarctic data in a greater spatial context.

\section{Short hand nomenclature of organic nitrates}

Schneider and Ballschmiter recently introduced a shorthand nomenclature of alkyl mononitrates that correlates the structure of a specific alkyl nitrate to the hydrocarbon precursor (Schneider and Ballschmiter,
1996). In our extended shorthand nomenclature the expression organic nitrates represents the whole family of mono- and multifunctional alkyl nitrates (Table 1) keeping the basic settings given by Schneider and Ballschmiter (Fischer et al., 2000).

The longest unbranched alkyl chain is taken as the skeleton of the molecule; e.g. C7 means in this case that the longest unbranched carbon chain has seven Catoms. Furthermore we define for unbranched alkyl nitrates that the nitrooxy group possesses the highest priority and is numbered first.

For branched alkyl nitrates the alkyl side chains possess now the highest priority above all other groups in the molecule, and therefore the positions of alkyl side chains are numbered first. $\mathrm{M}$ is used for methyl, and $\mathrm{E}$ is used for ethyl side chains, respectively.

This convention is particularly important and helpful if isomeric hydrocarbon skeletons have to be distinguished. For a better understanding we explain the abbreviations introducing some examples for alkyl mononitrates, alkyl dinitrates, hydroxy alkyl nitrates, keto alkyl nitrates, and alicyclic alkyl nitrates.

Alkyl mononitrates: 2,4M5C7 indicates a heptyl chain with two methyl groups at the 2 and 4 position and the nitrooxy group at the 5 position, specifically a 2,4-dimethyl-5-nitrooxyheptane.

Alkyl dinitrates: 2,3M1,4C5 would be a alkyl dinitrate with a carbon skeleton of five atoms, with two methyl groups at the 2 and 3 position, and two nitrooxy groups at position 1 and 4, specifically a 2,3-dimethyl1,4-dinitrooxy pentane.

Hydroxy alkyl nitrates: $\mathrm{OH}$ is used for the hydroxy group. 3OH1C4 would be 3-hydroxy-1-nitrooxy butane.

Keto alkyl nitrate: The letter $\mathrm{O}$ labels the carbonyl group, e.g. 2O1C5 is a 2-keto-1-nitrooxy pentane.

Alicyclic alkyl nitrates: The letters $c$ and $t$ are used for cis and trans positions, respectively. $\mathrm{Cy}$ indicates an alicyclic skeleton. $c 1,2 \mathrm{CyC} 6$ indicates a cis-1,2-dinitrooxy cyclohexane.

Aryl alkyl nitrates: Aryl alkyl nitrates are named considering the phenyl- or naphthyl group as a substituent of the alkyl chain (Woidich et al., 1999).

\section{Position of the Neumayer Research Station in the Antarctic}

The Neumayer Station $\left(70^{\circ} 39^{\prime} \mathrm{S}, 8^{\circ} 15^{\prime} \mathrm{W}\right)$ was established in 1992 on the Ekström Shelf Ice as a research observatory for geophysical, meteorological and air chemistry measurements. Fig. 1 shows the geographical position of the research station. The snow-covered station is located on shelf ice that is $200 \mathrm{~m}$ thick and almost flat. The shelf ice margin where supply ships (e.g. RV "Polarstern") dock is $10 \mathrm{~km}$ away. The isolated location 
Table 1

IUPAC and short style nomenclature of the alkyl mononitrates and short-chain alkyl hydroxy- and dinitrates identified in the Antarctic air samples

\begin{tabular}{|c|c|c|c|c|c|}
\hline No. & IUPAC & Abbreviation & No. & IUPAC & Abbreviation \\
\hline \multirow[t]{2}{*}{$\mathrm{C}_{n}$} & & & $\mathrm{C}_{n}$ & & \\
\hline & Alkyl mononitrates & & & Alkyl dinitrates & \\
\hline 1 & Nitrooxy-methane & $\mathrm{C} 1$ & 2 & 1,2-Dinitrooxy-ethane & $1,2 \mathrm{C} 2$ \\
\hline 2 & Nitrooxy-ethane & $\mathrm{C} 2$ & 3 & 1,2-Dinitrooxy-propane & $1,2 \mathrm{C} 3$ \\
\hline \multirow[t]{2}{*}{3} & 1-Nitrooxy-propane & $1 \mathrm{C} 3$ & & 1,3-Dinitrooxy-propane & $1,3 \mathrm{C} 3$ \\
\hline & 2-Nitrooxy-propane & $2 \mathrm{C} 3$ & 4 & 1,3-Dinitrooxy-butane & $1,3 \mathrm{C} 4$ \\
\hline \multirow[t]{3}{*}{4} & 1-Nitrooxy-butane & $1 \mathrm{C} 4$ & & 2,3-Dinitrooxy-butane & $2,3 \mathrm{C} 4$ \\
\hline & 2-Nitrooxy-butane & $2 \mathrm{C} 4$ & & 2-Methyl-1,2-dinitrooxy-propane & $2 \mathrm{M} 1,2 \mathrm{C} 3$ \\
\hline & 2-Methyl-1-nitrooxy-butane & $2 \mathrm{M} 1 \mathrm{C} 3$ & 5 & 2,3-Dinitrooxy-pentane & $2,3 \mathrm{C} 5$ \\
\hline \multirow[t]{4}{*}{5} & 1-Nitrooxy-pentane & $1 \mathrm{C} 5$ & 6 & 2-Methyl-3,4-dinitrooxy-pentane & $2 \mathrm{M} 3,4 \mathrm{C} 5$ \\
\hline & 2-Nitrooxy-pentane & $2 \mathrm{C} 5$ & & Hydroxy alkyl nitrates & \\
\hline & 3-Nitrooxy-pentane & $3 \mathrm{C} 5$ & 3 & 1-Hydroxy-2-nitrooxy-propane & $1 \mathrm{OH} 2 \mathrm{C} 3$ \\
\hline & 2-Methyl-3-nitrooxy-butane & $2 \mathrm{M} 3 \mathrm{C} 4$ & & 2-Hydroxy-1-nitrooxy-propane & $2 \mathrm{OH} 1 \mathrm{C} 3$ \\
\hline \multirow[t]{3}{*}{6} & 1-Nitrooxy-hexane & $1 \mathrm{C} 6$ & 4 & 3-Hydroxy-2-nitrooxy-butane & $3 \mathrm{OH} 2 \mathrm{C} 4$ \\
\hline & 2-Nitrooxy-hexane & $2 \mathrm{C} 6$ & & 4-Hydroxy-2-nitrooxy-butane & $4 \mathrm{OH} 2 \mathrm{C} 4$ \\
\hline & 3-Nitrooxy-hexane & $3 \mathrm{C} 6$ & 5 & 2-Hydroxy-1-nitrooxy-pentane & $2 \mathrm{OH} 1 \mathrm{C} 5$ \\
\hline \multirow[t]{4}{*}{7} & 1-Nitrooxy-heptane & $1 \mathrm{C} 7$ & & 1-Hydroxy-2-nitrooxy-pentane & $1 \mathrm{OH} 2 \mathrm{C} 5$ \\
\hline & 2-Nitrooxy-heptane & $2 \mathrm{C} 7$ & 6 & 2-Hydroxy-3-nitrooxy-hexane & $2 \mathrm{OH} 3 \mathrm{C} 6$ \\
\hline & 3-Nitrooxy-heptane & $3 \mathrm{C} 7$ & & 4-Hydroxy-3-nitrooxy-hexane & $4 \mathrm{OH} 3 \mathrm{C} 6$ \\
\hline & 4-Nitrooxy-heptane & $4 \mathrm{C} 7$ & & 2-Methyl-4-hydroxy-5-nitrooxy-pentane & $2 \mathrm{M} 4 \mathrm{OH} 5 \mathrm{C} 5$ \\
\hline 8 & 1-Nitrooxy-octane & $1 \mathrm{C} 8$ & & 2-Methyl-5-hydroxy-4-nitrooxy-pentane & 2M5OH4C5 \\
\hline
\end{tabular}

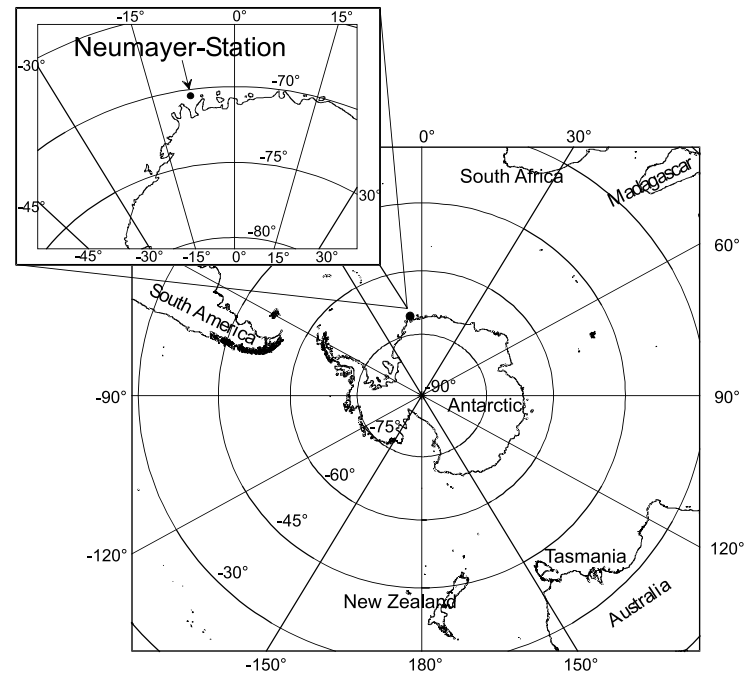

Fig. 1. Geographical position of Neumayer Station; on the Ekström Shelf ice in the Atka Bay, Northeast Weddell Sea $\left(70^{\circ} 39^{\prime \prime} \mathrm{S}, 8^{\circ} 15^{\prime \prime} \mathrm{W}\right)$.

of the station makes it a valuable reference site for measurements under conditions of extreme air purity. In addition, the proximity to the ice margin permits the detection of substances released from the ocean to the atmosphere. Table 2 summarizes the meteorological parameters related to the Neumayer Station during the sampling period.

\section{Experimental}

\subsection{Air sampling procedure}

The air sampling was done by pulling air through glass tubes ( $160 \mathrm{~mm}$ length, $3 \mathrm{~mm}$, i.d.) filled with 80 $100 \mathrm{mg}$ of Tenax TA, 60-80 mesh (Chrompack, Middelburg, Netherlands) at a flow rate of $80-100 \mathrm{ml} / \mathrm{min}$ with a sampling pump (SKC model 222-3, Eighty Four, Pennsylvania, United States). Two sampling tubes connected in series have been used to control the sampling efficiency. Volumes of 2-68 1 air were sampled. The sampling tubes were flame-sealed in larger glass tubes for transport and were kept refrigerated until analysis.

To detect the whole range of alkyl nitrates parallel sampling of low volumes of 21 for C2 up to C5 alkyl nitrates and high volumes of 50-70 1 as well for alkyl nitrates $\mathrm{C}>5$ is recommended. In polar regions the breakthrough loss due to sampling temperatures is negligible.

\subsection{Analytical procedure: GC separation, detection and quantitation}

The high resolution gas chromatography with electron capture detection (HRGC/ECD) chromatographic separation was performed on a Chrompack Model 9001 gas chromatograph equipped with a thermal desorption cold trap (TCT) device (Chrompack, Middelburg, 
Table 2

Meteorological parameters related to the Antarctic air samples

\begin{tabular}{llccccc}
\hline Sample & Date & $\begin{array}{l}\text { Sample volume } \\
(\mathrm{l})\end{array}$ & $\begin{array}{l}\text { Air temperature } \\
\left({ }^{\circ} \mathrm{C}\right)\end{array}$ & Wind direction & $\begin{array}{l}\text { Wind velocity } \\
\left(\mathrm{m} \mathrm{s}^{-1}\right)\end{array}$ & Humidity $(\%)$ \\
\hline NM 1 & 13.02 .1999 & 2.0 & -7.5 & $130^{\circ} \mathrm{SE}$ & 4 & 75 \\
NM 2 & 22.02 .1999 & 30.2 & -5.5 & $75^{\circ} \mathrm{ENE}$ & 5 & 73 \\
NM 3 & 22.02 .1999 & 68.0 & -10.0 & $160^{\circ} \mathrm{ESE}$ & 3 & 87 \\
NM 4 & 26.02 .1999 & 10.8 & -6.3 & $90^{\circ} \mathrm{E}$ & 12 & 96 \\
\hline
\end{tabular}

Netherlands). We used a DB-1701 capillary $(58 \mathrm{~m} \times$ $0.312 \mathrm{~mm}$ i.d. $\times 1.0 \mu \mathrm{m}$ film thickness, J\&W Scientific, Folsom, United States). A detailed description of the analytical conditions is given in (Fischer et al., 2000). Quantitation was done by external calibration with solutions containing known amounts of alkyl nitrates and halocarbons. The limit of detection based on a 301 air sample was about $0.3 \mathrm{ng} / \mathrm{m}^{3}$ or $0.05 \mathrm{ppt}(\mathrm{v})$ for alkyl nitrates and $0.2 \mathrm{ng} / \mathrm{m}^{3}$ or $0.02 \mathrm{ppt}(\mathrm{v})$ for the three halocarbons trichloroethane, tetrachloroethene and bromoform. The overall error for the alkyl nitrates and halocarbons was estimated to be less than $\pm 20 \%$ (Fischer, 1999).

\section{Results}

The measured concentrations of organic nitrates and halocarbons of this work are summarized in Table 3. The results presented in this work are unique for organic nitrates. Table 4 lists all literature data and compares them with the results of this work. Highest in abundance are the short chain alkyl mononitrates $\mathrm{C} 2,1 \mathrm{C} 3,2 \mathrm{C} 3$ and 2C4. This observation is consistent with the literature data for Arctic regions (Table 4). The alkyl nitrate levels for the Arctic regions are one order of magnitude higher than the values found in the Antarctic, indicating that the sampling sites in the North are closer to the highly industrialized regions of the North American continent. In terms of the vicinity to non-point sources the Arctic and Antarctic regions have to be considered differently; the effects of a limited photodegradation in the respective polar nights will be similar.

Fig. 2a and b depict TCT-HRGC-ECD chromatograms of air samples collected at Neumayer Station, Antarctica. To our knowledge these are the first chromatograms showing alkyl nitrates in the air of a South Polar region.

The biogenic marker dibromomethane and tribromomethane (bromoform) show relative to alkyl nitrates higher mixing ratios indicating marine emissions sources (the sampling location is only $10 \mathrm{~km}$ away from the coastal line). Anthropogenic markers like carbontetrachloride and 1,1,1-trichloroethane with long $k_{\mathrm{OH}}$

Table 3

Mixing ratios for the alkyl mononitrates, hydroxy alkyl nitrates, alkyl dinitrates, and bromo- and chloro-halocarbons in the Antarctic air in $\operatorname{ppt}(\mathrm{v})(n=2-4)$

\begin{tabular}{|c|c|c|c|c|c|}
\hline Mononitrates & Mean (ppt(v)) & Hydroxy nitrates & Mean (ppt(v)) & Halocarbons & Mean $(\operatorname{ppt}(\mathrm{v}))$ \\
\hline $\mathrm{Cl}(n=1)$ & 84 & $2 \mathrm{OH} 1 \mathrm{C} 4$ & $<$ LOD & Tetrachloromethane & 95 \\
\hline $\mathrm{C} 2$ & 4.6 & $2 \mathrm{OH} 1 \mathrm{C} 3$ & 0.03 & 1,1,1-Trichloroethane & 75 \\
\hline $1 \mathrm{C} 3$ & 1.1 & $\mathrm{RR}-3 \mathrm{OH} 2 \mathrm{C}^{\mathrm{a}}$ & 0.3 & Trichlorethene & $<$ LOD \\
\hline $2 \mathrm{C} 3$ & 0.7 & $1 \mathrm{OH} 2 \mathrm{C} 3 / \mathrm{RS}-3 \mathrm{OH} 2 \mathrm{C}^{\mathrm{a}}$ & 0.8 & Tetrachlorethene & 0.3 \\
\hline $1 \mathrm{C} 4$ & 0.03 & & & Hexachloroethane & 0.06 \\
\hline $2 \mathrm{C} 4 / 2 \mathrm{M} 1 \mathrm{C} 3$ & 0.5 & $1 \mathrm{OH} 2 \mathrm{C} 4$ & 0.02 & Dibromomethane & 0.8 \\
\hline $1 \mathrm{C} 5$ & 0.7 & $3 \mathrm{OH} 1 \mathrm{C} 4$ & 0.01 & Bromodichloromethane & 0.05 \\
\hline $2 \mathrm{C} 5$ & $<$ LOD & $\sum \mathrm{OH}$ & 1.1 & Dibromochloromethane & 0.02 \\
\hline \multirow[t]{3}{*}{$3 \mathrm{C} 5$} & 0.03 & & & Bromoform & 0.3 \\
\hline & & & & 1,2-Dibromoethane & 0.1 \\
\hline & & Dinitrates & & & \\
\hline $1 \mathrm{C} 6$ & 0.5 & $1,2 \mathrm{C} 3 / 1,2 \mathrm{C} 2$ & 0.5 & & \\
\hline $2 \mathrm{C} 6$ & 1.0 & $2 \mathrm{M} 1,2 \mathrm{C} 3$ & 0.1 & & \\
\hline $3 \mathrm{C} 6$ & 0.08 & & & & \\
\hline $2 \mathrm{C} 7$ & 0.18 & $\sum \mathrm{C} 4+\mathrm{C} 5$ & 1.3 & & \\
\hline $4 \mathrm{C} 7$ & 0.02 & $\sum \mathrm{C} 3-\mathrm{C} 6$ & 4.6 & & \\
\hline
\end{tabular}

Limit of detection $(\mathrm{LOD})=0.01 \mathrm{ppt}(\mathrm{v})$.

${ }^{\mathrm{a}} \mathrm{RR} / \mathrm{SS}-3 \mathrm{OH} 2 \mathrm{C} 4$; RS/SR-3OH2C4 co-elution with $1 \mathrm{OH} 2 \mathrm{C} 3$. 
Table 4

Comparison of mixing ratios of alkyl nitrates in the Antarctic air with Arctic and Alaska reference data in ppt(v)

\begin{tabular}{|c|c|c|c|c|}
\hline & \multirow[t]{2}{*}{ Antarctic (this work) } & \multicolumn{2}{|c|}{ Alert, Canada } & \multirow[t]{2}{*}{ Arctic, Canada ${ }^{a}$} \\
\hline & & Polar night ${ }^{b}$ & Polar day ${ }^{b}$ & \\
\hline $1 \mathrm{C} 3$ & 1.11 & 3.33 & 3.14 & 3.96 \\
\hline $2 \mathrm{C} 3$ & 0.49 & 12.44 & 13.08 & 12.5 \\
\hline $1 \mathrm{C} 4$ & 0.03 & 1.7 & 1.18 & 2.05 \\
\hline $2 \mathrm{C} 4 / 2 \mathrm{M} 1 \mathrm{C} 3$ & 0.48 & 18.41 & 13.73 & 13.98 \\
\hline $2 \mathrm{M} 3 \mathrm{C} 4$ & $<$ LOD & 4.84 & 2.32 & 2.65 \\
\hline $1 \mathrm{C} 5$ & 0.71 & 1.01 & 0.53 & 1.03 \\
\hline $2 \mathrm{C} 5$ & $<$ LOD & 5.44 & 2.47 & 4.18 \\
\hline $3 \mathrm{C} 5$ & 0.03 & 4.31 & 2.31 & 3.02 \\
\hline $2 \mathrm{C} 6$ & 0.08 & 2.46 & 0.98 & 1.50 \\
\hline $3 \mathrm{C} 6$ & 0.95 & 4.27 & 1.65 & 2.55 \\
\hline $2 \mathrm{C} 7$ & 0.18 & 1.45 & 0.56 & - \\
\hline $3 \mathrm{C} 7$ & $(0.01)$ & 1.86 & 0.68 & - \\
\hline$\sum \mathrm{C} 2-\mathrm{C} 6$ & 9.2 & - & - & $34^{\mathrm{c}}$ \\
\hline$\sum \mathrm{C} 3-\mathrm{C} 7$ & - & - & - & $144^{\mathrm{d}}$ \\
\hline
\end{tabular}

Limit of detection $(\mathrm{LOD})=0.01 \mathrm{ppt}(\mathrm{v})$.

${ }^{a}$ Canadian Arctic $\left(69^{\circ} \mathrm{N}-83^{\circ} \mathrm{N}\right)$ "Polar Sunrise Experiment" April 1992 (Leaitch et al., 1994).

b Alert, Northwest Territories of Canada, "Polar Sunrise Experiment" January-April 1992, Polar night January-March; day period March-April (Muthuramu et al., 1994).

${ }^{\mathrm{c}}$ Poker Flat Research Rang, Alaska $\left(64^{\circ} \mathrm{N} / 147^{\circ} \mathrm{W}\right)$ winter/spring 1993 (Beine et al., 1996).

${ }^{\mathrm{d}}$ Canadian Arctic March-April 1988 (Bottenheim et al., 1993).

lifetimes $(\tau=$ month to years) were also found, but markers with short $k_{\mathrm{OH}}$ lifetime like trichloroethene ( $\tau=7$ days $)$ are below the limit of detection $(<0.01$ $\operatorname{ppt}(\mathrm{v}))$.

The patterns of the Antarctic air samples are quite similar to the patterns found in the South Atlantic Trade Wind region. Fig. 2c depicts for comparison a chromatogram of this marine region, taken during the ALBATROSS campaign on board of RV "Polarstern" (ANT XIV/1) at $10.4^{\circ} \mathrm{S} / 25.5^{\circ} \mathrm{W}$ (Fischer et al., 2000). The Antarctic and the Southern Trades apparently represent baseline levels of clean marine air in terms of organic nitrates.

\subsection{Levels of anthropogenic halocarbons in Antarctic air}

The mixing ratios for the long-lived halocarbons (Table 3) are in good agreement with earlier measurements. We found $95 \mathrm{ppt}(\mathrm{v})$ for tetrachloromethane $(\tau=42 a)$ while Derwent measured $101 \operatorname{ppt}(\mathrm{v})$ in Ireland (Derwent et al., 1998). This indicates a more or less even global distribution in the troposphere. For 1,1,1-trichlorethane we observed $75 \operatorname{ppt}(\mathrm{v})(\tau=4.8 a)$; estimations by Derwent for 1999 results in ratios of 70-80 ppt(v) (Derwent et al., 1998). The situation seems to be similar as observed for tetrachloromethane. The mean value for hexachloroethane is in the range of $0.06 \operatorname{ppt}(\mathrm{v})$ and somewhat lower than $0.24 \mathrm{ppt}(\mathrm{v})$ observed by Atlas in 1993 for the Pacific (Atlas et al., 1993). For medium lived $\mathrm{C}_{2}^{-}$halocarbons like tetrachlorethene we observed a mean value of $0.3 \operatorname{ppt}(\mathrm{v})$. During the AlbatrossCampaign we found similar mixing ratios in the South Atlantic Ocean and levels by a factor 3 higher for the North Atlantic (Fischer et al., 2000). The good correlation of the measured halocarbon ratios with literature data backs the accuracy of our analytical procedure.

\section{Discussion}

To interpret the data of the South Polar region in a wider spatial context we enclose the data of the Albatross-Campaign, which also covered the South Atlantic (Fischer et al., 2000).

\subsection{Levels of butyl nitrates in marine and Antarctic air}

Fig. 3 is a plot of the mixing ratios of the $2 \mathrm{C} 4$, the secondary, and the $1 \mathrm{C} 4$, the primary butyl nitrate along the Atlantic Ocean (Albatross-Campaign) and at Neumayer Station, Antarctic. The main emission sources are in the industrialized areas of the Northern hemisphere. The accumulation in the Northern hemisphere is enhanced in fall and wintertime by a reduced photodegradation. The concentration for 2-butyl nitrate (2C4) in the coastal region is $3.5-5 \mathrm{ppt}(\mathrm{v})$. An average value of $1 \pm 0.2 \mathrm{ppt}(\mathrm{v})$ is observed for 1-butyl nitrate (1C4) in the air of the North Atlantic. A 2C4/1C4 ratio close to 4 indicates a recent continental input or marine local input by islands. 

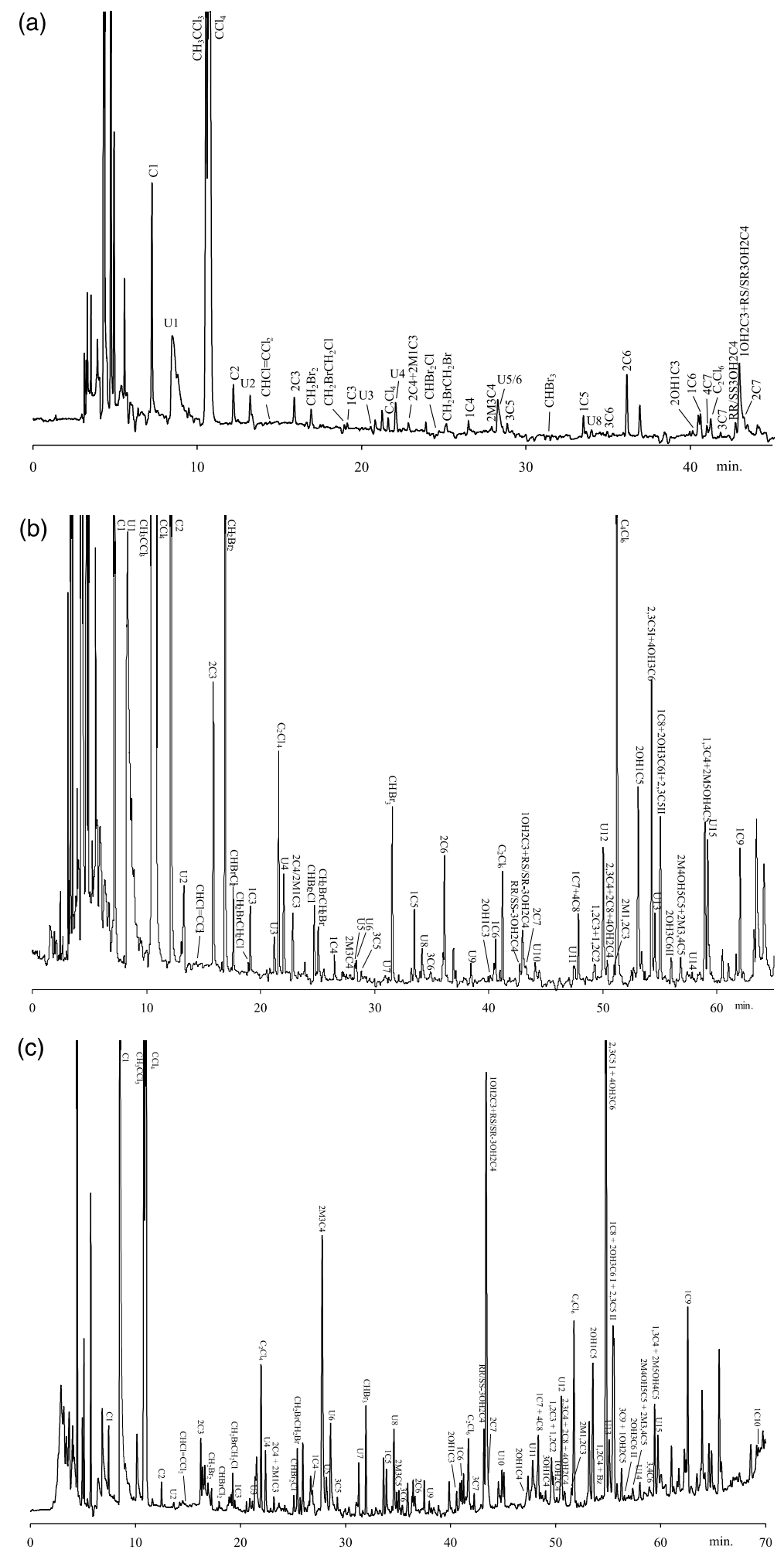

Fig. 2. (a) TCT-HRGC(DB-1701)/ECD chromatogram of an Antarctic air sample, taken at Neumayer Station, sampling and oncolumn volume (a) 2.01 (sample NM 1), (b) 681 (sample NM 3). (c) TCT-HRGC(DB-1701)/ECD chromatogram of a South Atlantic air sample of the trade wind region $10.4^{\circ} \mathrm{S} / 25.5^{\circ} \mathrm{W}$, sampling and on-column volume 1051 . 


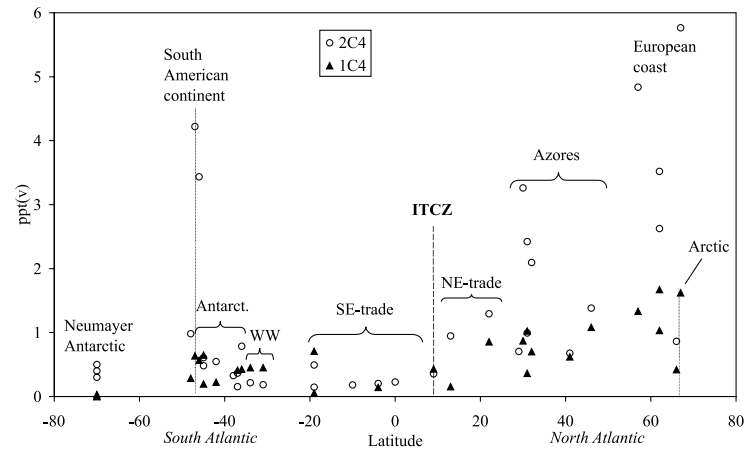

Fig. 3. Distribution of butyl nitrates from $67^{\circ} \mathrm{N}$ to $70^{\circ} \mathrm{S}$ over the Atlantic Ocean mainly across $30^{\circ} \mathrm{W}$ longitude (AlbatrossCampaign on board RV Polarstern ANT XIV/1, 1996) and at the Neumayer Station, 1999.

In the South Atlantic trade wind region the values for $2 \mathrm{C} 4$ decrease to $0.2 \pm 0.05 \mathrm{ppt}(\mathrm{v})$ leading to a $2 \mathrm{C} 4 / 1 \mathrm{C} 4$ ratio to about 1 and even below 1 . The levels of $2 \mathrm{C} 4$ rise again to $0.4 \pm 0.08 \mathrm{ppt}(\mathrm{v})$ in the west wind belt of the South Atlantic and remain at $0.4 \pm 0.1 \mathrm{ppt}(\mathrm{v})$ for air collected at the Neumayer Station. The levels of 1C4 decrease from $1.0 \pm 0.2 \mathrm{ppt}(\mathrm{v})$ in the Northern hemisphere passing the intertropical convergence zone (ITCZ) to the south to levels of $0.4 \pm 0.08 \operatorname{ppt}(\mathrm{v})$. A further decrease to levels down to the limit of detection of 0.05 $\operatorname{ppt}(\mathrm{v})$ is observed for the air at the Neumayer Station. The $2 \mathrm{C} 4 / 1 \mathrm{C} 4$ ratio covers a span between 0.2 and 7.0 reflecting in one part the dominance of $1 \mathrm{C} 4$ in "old" air masses and also a very low level of possible local input in the Antarctic. In the latter case only the dominant 2C4 would be detected.

\subsection{Characterization of the age of air masses}

An air mass is called "young" if pollution deriving from densely inhabited regions with a corresponding level of traffic and industrial emissions is observed. Several attempts have been made to characterize air mass ages. Atherton used a pure deductive kinetic model (Atherton, 1989). Other models consider differences in photochemical degradation velocities using pairs of molecules or groups of molecules like carbon monoxide and alkyl nitrates (Roberts et al., 1996), PAN and alkyl nitrates (Buhr et al., 1990), hydrocarbons and alkyl nitrates (Roberts et al., 1998), $\mathrm{NO}_{y}$ and $\mathrm{NO}_{x}$ (Trainer et al., 1991), two isomeric alkyl nitrates (Flocke et al., 1998; Schneider and Ballschmiter, 1999) or consider the presence of benzyl nitrate (Schneider et al., 1998a; Schneider and Ballschmiter, 1999). Here we present two different approaches to characterize the "age" of air masses. It is the 2-butyl-, 2-pentyl nitrate/tetrachloroethene quotient (traffic/industry indicator) and the ratio of isomeric pentyl nitrates (traffic indicator).

\subsection{The 2-butyl-, 2-pentyl nitrateltetrachlorethene ratio as an air mass marker}

Here, we present a method based on the differences in the degradation rates of short chain alkyl nitrates and semi-stable halocarbons (e.g. tetrachloroethene). Short chain alkyl nitrates are formed in all regions with traffic that are releasing significant NO and short chain hydrocarbon emissions. Butyl- and pentyl nitrates are degraded by photolysis and $\mathrm{OH}$ on their long-range transport finally reaching remote areas like the Antarctic. The anthropogenic halocarbons emerge basically from industrialized continental regions and then undergo photochemistry on their long-range transport. They are degraded mainly by $\mathrm{OH}$ radicals and only to a minor extent by photolysis (Class and Ballschmiter, 1986).

The $k_{\mathrm{OH}}$ lifetime of tetrachloroethene is in the range of 4 month. Tetrachloroethene shows a three-step decrease in the global mixing ratios in the lower troposphere (Wiedmann et al., 1994). A first decrease is observed when going from continental air to marine air of the Northern hemisphere. This is a mixture of a decrease by degradation and by mixing of the source air with less polluted air of the Northern Hadley cell of the general circulation. The second decrease is observed in the Northern tropics and a third one when passing the ITCZ reaching the air of South East Trades of the Southern hemisphere. This clearly indicates the separation of the air masses of both hemispheres in the lower troposphere by the ITCZ. This has been observed for other anthropogenic volatile chlorocarbons before (Class and Ballschmiter, 1986).

The butyl nitrates do not give this clear difference in atmospheric levels but decrease more or less continuously in going to remote regions. The increased levels around the Azores indicate the importance of quasilocal inputs in the marine atmosphere due to traffic on these islands. Fig. 5a depicts the ratios of the mixing ratios of the secondary alkyl nitrates 2-butyl- and 2pentyl nitrate relative to tetrachloroethene $\left(\mathrm{C}_{2} \mathrm{Cl}_{4}\right)$ in the air of the Atlantic Ocean and in the air of Neumayer Station. Three clusters are formed. Marine air influenced by air masses coming from the South American continent is characterized by a surplus of 2-butyl and 2-pentyl nitrates relative to tetrachloroethene. Unpolluted marine air has low mixing ratios for 2-pentyl nitrate itself and the ratio $2 \mathrm{C} 5 / \mathrm{C}_{2} \mathrm{Cl}_{4}$ is $<1$ indicating a strong degradation for 2-pentyl nitrate. The third cluster represents the global baseline level. It is characterized by the fact that both the ratios for $2 \mathrm{C}_{4} / \mathrm{C}_{2} \mathrm{Cl}_{4}$ and $2 \mathrm{C} 5 / \mathrm{C}_{2} \mathrm{Cl}_{4}$ 
are well below 1 . This third cluster represents the photochemically aged pollution depleted air masses.

\subsection{The ratio of isomeric pentyl nitrates as an air mass marker}

A further method to decide about the origin or age of an air parcel is to compare the levels of the isomeric pentyl nitrates. In the case of pentyl nitrates significantly increased mixing ratios for primary and secondary pentyl nitrates are found with a surplus of secondary pentyl nitrates $(3 \mathrm{C} 5>2 \mathrm{C} 5>1 \mathrm{C} 5)$. Very low concentrations of secondary pentyl nitrates, and in contrast noticeably higher concentrations of 1-pentyl nitrates characterize aged air masses (e.g. collected in remote marine or Antarctic regions). The former sequence of the levels in air $3 \mathrm{C} 5>2 \mathrm{C} 5>1 \mathrm{C} 5$ turns now to $1 \mathrm{C} 5 \gg 3 \mathrm{C} 5>2 \mathrm{C} 5$. The mixing ratio for $2 \mathrm{C} 5$ in the air of the Antarctic Neumayer Station is below the limit of detection (Table 3). The missing of 2C5 and barely detectable traces of 3C5 while 1C5 can be measured confirm that highly degraded air masses were collected.

\subsection{Methyl nitrate in Antarctic air}

The level found for methyl nitrate found in the Antarctic is unexpectedly high and requires a specific discussion. The branching ratio for the atmospheric reaction Eqs. (7a)-(7c) is normally set close to zero for $\mathrm{C} 1$. Degradation of peroxyacetylnitrate (PAN) by the loss of $\mathrm{CO}_{2}$ or the esterfication of methanol with nitric acid on aerosols (Senum et al., 1986; Orlando et al., 1992; Fan et al., 1994) can result in higher yields of metyl nitrate in polluted continental air.

The reaction of methyl nitrate with $\mathrm{OH}$ is the major loss process. The reaction rate constant was first measured by Gaffney et al. (Gaffney et al., 1986). It has recently be redetermined (Kakesu et al., 1997).

Methyl nitrate is very volatile and substantial breakthrough losses will occur if not specific precautions (low sample volume, high amount of adsorbent, low temperature) are set to sample this very volatile alkyl nitrate by adsorption techniques. A correct quantitation of methyl nitrate is therefore difficult and requires optimized sampling conditions. We have found a level of $>80 \operatorname{ppt}(\mathrm{v})$ for methyl nitrate in the low volume sample. Co-elution with other compounds in the gas chromatogram of our sample can be excluded by identification of the $\mathrm{C} 1$ peak by HRGC/MSD. Recently Jones measured methyl nitrate from 27 to $46 \operatorname{ppt}(\mathrm{v})$ and ethyl nitrate from 5 to $13 \operatorname{ppt}(v)$ sampled at Neumayer Station 1997 (Jones et al., 1999).

Walega et al. found for methyl nitrate $4 \operatorname{ppt}(v)$ at Mauna Loa, Hawaii (Walega et al., 1992) and Flocke et al. measured $8 \operatorname{ppt}(v)$ in the air over the North Atlantic (Flocke et al., 1998). Atlas supposed a marine emission source for methyl nitrate (Atlas et al., 1997). In the marine boundary layer (MBL) maximum concentrations were found as high as $50 \mathrm{ppt}(\mathrm{v})$ near Christmas Island $\left(1-3^{\circ} \mathrm{N}\right)$ and concentrations of $20-35 \mathrm{ppt}(\mathrm{v})$ near Western Samoa $\left(13^{\circ} \mathrm{S}\right)$ during ACE 1 (Blake et al., 1999). The authors conclude that methyl nitrate has a significant equatorial marine source. The most logic biogenic source would be the methylation of nitrate ions. We may observe a similar reaction for the nitrate ion leading to methyl nitrate as it is found for the methylation of chloride (Urhahn and Ballschmiter, 1998). Methionine methyl sulfonium chloride (MMSL) e.g. gave an intense release of monohalomethanes when mixed in a buffer with potassium halides.

\subsection{Levels of hydroxy alkyl nitrates in marine and Antarctic air}

Fig. 4 is a plot of the mixing ratios of hydroxy alkyl nitrates along the Atlantic Ocean (Albatross-Campaign) and at Neumayer Station, Antarctic. All of the observed compounds are vicinal hydroxy alkyl nitrates. Hence, their formation pathway via $\mathrm{OH}$ radical addition to olefins is most likely. We observe a NH/SH gradient of about factor 3 with $4.3 \pm 0.8 \operatorname{ppt}(\mathrm{v})$ for the sum of 4 hydroxy alkyl nitrates in the air of the Northern hemisphere and $1.6 \pm 0.3 \operatorname{ppt}(\mathrm{v})$ in the South Atlantic air. The mixing ratio for hydroxy alkyl nitrates in the air of the Neumayer Station is with $1.2 \pm 0.2 \mathrm{ppt}(\mathrm{v})$ somewhat lower than in the South Atlantic air. In accordance with previous discussions the formation of secondary alkyl radicals is preferred to the formation of primary ones (Kastler, 1999). Therefore, if 1-alkenes are degraded by $\mathrm{OH}$ radicals, the yield of 1-hydroxy-2-nitrooxy-alkanes must be higher than the yield for 2-hydroxy-1-nitrooxy alkanes. This is consistent with our observations.

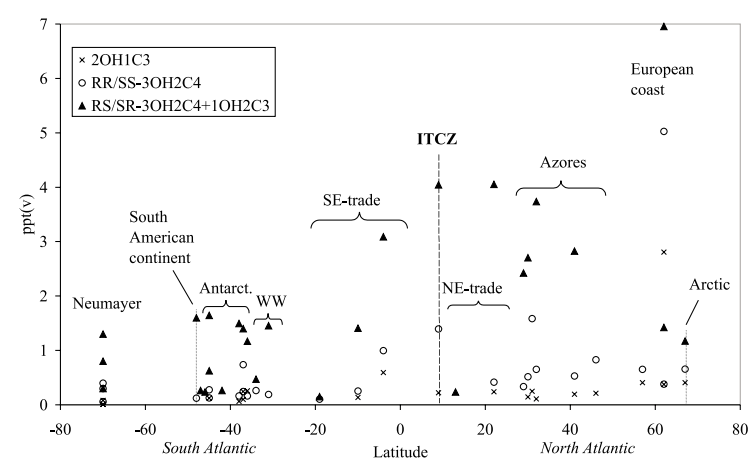

Fig. 4. Distribution of hydroxy propyl- and butyl nitrates from $67^{\circ} \mathrm{N}$ to $70^{\circ} \mathrm{S}$ over the Atlantic Ocean and at Neumayer Station. 


\subsection{Principal compound analysis (PCA) of organic nitrates in marine and Antarctic air}

The principal compound analysis is a statistical model to compare the pattern of air samples between different regions. The theoretical feedback of the method is given in (Smith, 1991). The $n$-dimensional expression is reduced to a two dimensional expression. The distance between two points is a measure of the similarity of air samples. Fig. 5b depicts the PCA of all marine and Antarctic air samples. 15 locations and the ratios of 14 alkyl mononitrates are the basis for the PCA given here.

A grouping of air masses is also obtained by plotting two ratios of selected air constituents. This approach has been used to characterize air masses by their complex pattern of polychlorinated biphenyls (PCBs) (Schreitmüller et al., 1994). We have plotted here the ratios of the mixing ratio of 2-butyl nitrate/tetrachloroethene versus 2-pentyl nitrate/tetrachlorethene. The results are given in Fig. 5a. Three clusters of air masses can be differentiated. Cluster I contains all sampling locations representing global baseline levels. Cluster II summarizes marine air samples with slightly polluted air, indi-

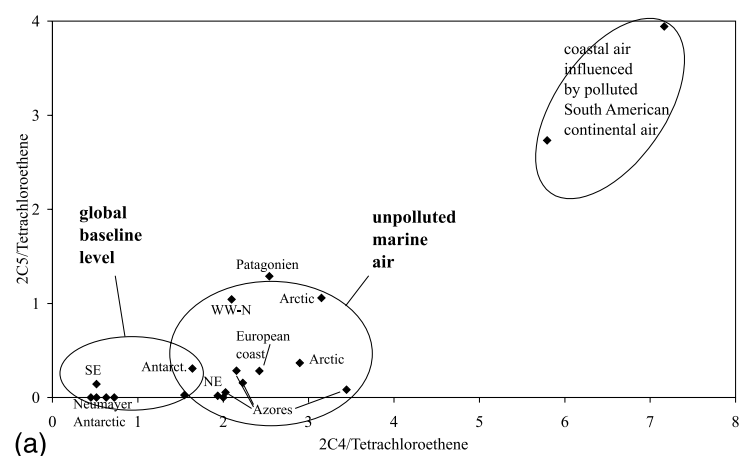

(a)

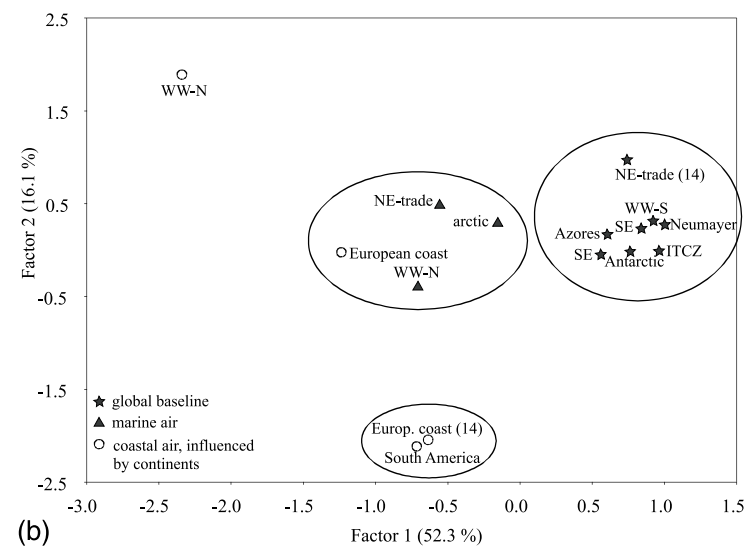

Fig. 5. Grouping of air masses by (a) mixing ratio of 2-butyl nitrate/tetrachloroethene versus 2-pentyl nitrate/tetrachlorethene, (b) PCA of organic nitrates in marine air. cating the influence of islands. The last cluster contains polluted air coming in from the South American continent. The PCA as an independent method confirms the characterization of marine and polar air samples as discussed above.

\section{Conclusion}

In this paper we presented for the first time a data set of higher organic nitrates in the air of the German South Polar Neumayer Station. We are in a unique position to discuss and compare the levels and patterns of alkyl nitrates and halocarbons in the air of the Atlantic Ocean and in the air of the South Polar region. The organonitrate concentrations in the marine and Antarctic samples reached only $1-10 \%$ of the continental samples. The mixing ratio in the South East Trade Wind region and in the air of Neumayer Station are similar and represents the global baseline level for the organonitrates. This is a strong indication for the long-range transport of these molecules. No new alkyl nitrate formation is expected due to the lack of $\mathrm{NO}_{x}$ sources in the marine and the Antarctic atmosphere. Methyl nitrate seems to be the exception from this rule. A biogenic source for this compound appears to be likely as it has been discussed before.

Halocarbons can be used as marker molecules to distinguish between inhabited and biogenic sources. The ratio of tetrachloroethene to secondary alkyl nitrates can be used as a tool to decide about the origin and age of an air parcel analyzed. The ratio of the isomeric pentyl nitrates can also be used to characterize air masses.

\section{References}

Ahlner, J., Andersson, R.G.G., Torfgard, K., Axelsson, K.L., 1991. Organic nitrate esters: Clinical use and mechanisms of actions. Pharmacol. Rev. 43, 351-353.

Atherton, C.S., 1989. Organic nitrates in remote marine environments: evidence for long- range transport. Geophys. Res. Lett. 16, 1289-1292.

Atkinson, R., 1990. Gas-phase tropospheric chemistry of organic compounds: a review. Atmos. Environ. 24A, 1-41.

Atkinson, R., Aschmann, S.M., Carter, W.P.L., Winer, A.M., Pitts, J.N., 1982. Alkyl nitrates formation from the $\mathrm{NO}_{x}$-air photooxidations of C2-C 8 -alkanes. J. Phys. Chem. 86, 4563-4569.

Atlas, E., 1988. Evidence for $>$ C3 alkyl nitrates in rural and remote atmospheres. Nature 331, 426-428.

Atlas, E., Flocke, F., Schauffler, S., Stroud, V., Blake, D., Rowland, F.S., Singh, H., 1997. Evidence for marine sources of atmospheric alkyl nitrates: measurements over the tropical Pacific Ocean during PEM tropics. Posterbeitrag, American Geophysical Union (AGU) 78 (46) Fall Meeting, Supplement. 
Atlas, E., Pollock, W., Greenberg, J., Heidt, L., 1993. Alkyl nitrates, nonmethane hydrocarbons and halocarbon gases over equatorial Pacific Ocean during Saga 3. J. Geophys. Res. 98, 16933-16947.

Atlas, E., Ridley, B.A., Hübler, G., Walega, J.G., Carroll, M.A., Montzka, D.D., Huebert, B.J., Norton, R.B., Grahek, F.E., Schauffler, S., 1992a. Partitioning and budget of $\mathrm{NO}_{y}$ species during the Mauna Loa Observatory Photochemistry Experiment. J. Geophys. Res. 97, 10 449-10 462.

Atlas, E., Schauffler, S.M., Merrill, J.T., Hahn, J., Ridley, B.A., Walega, J.G., Greenberg, J., Heidt, L., Zimmerman, P.B., 1992b. Alkyl nitrate and selected halocarbon measurements at Mauna Loa Observatory, Hawaii. J. Geophys. Res. 97, $10331-10348$.

Barrie, L.A., Li, S.M., Toom, D.L., Landsberger, S., Sturges, W.T., 1994. Lower tropospheric measurements of halogens, nitrates, and sulphur oxides during Polar Sunrise Experiment 1992. J. Geophys. Res. 99, 25 453-25467.

Beine, H.J., Jaffe, D.A., Blake, D.R., Atlas, E., Harris, J., 1996. Measurement of PAN, alkyl nitrates, ozone, and hydrocarbons during spring in interior Alaska. J. Geophys. Res. 101, 12 613-12619.

Blake, N.J., Blake, D.R., Wingenter, O.W., Sive, B.C., Kang, C.H., Thornton, D.C., Bandy, A.R., Atlas, E., Flocke, F., Harris, J.M., Rowland, F.S., (1999). Aircraft measurements of the latitudinal, vertical, and seasonal variations of NMHCS, methyl nitrate, methyl halides, and DMS during the first aerosol characterization experiment. (ACE 1) J. Geophys. Res. 104, 21 803-21817.

Bottenheim, J.W., Barrie, L.A., Atlas, E., 1993. The partitioning of nitrogen oxides in the lower Arctic troposphere during spring 1988. J. Atmos. Chem. 17, 15-27.

Buhr, M.P., Parrish, D.D., Norton, R.B., Fehsenfeld, F.C., Sievers, R.E., 1990. Contribution of organic nitrates to the total reactive nitrogen budget at a rural Eastern US site. J. Geophys. Res. 95, 9809-9816.

Carroll, M.A., Ridley, B.A., Montzka, D.D., Hübler, G., Walega, J.G., Norton, R.B., Huebert, B.J., Grahek, F.E., 1992. Measurements of nitric oxide and nitrogen dioxide during the Mauna Loa Observatory Photochemistry Experiment. J. Geophys. Res. 97, $10361-10374$.

Class, T., Ballschmiter, K., 1986. Chemistry of organic traces in air VI: distribution of chlorinated $\mathrm{Cl}-\mathrm{C} 4$ hydrocarbons in air over the northern and Southern Atlantic Ocean. Chemosphere 15, 413-427.

Clemitshaw, K.C., Williams, J., Rattigan, O.V., Shallcross, D.E., Law, K.S., Cox, R.A., 1997. Gas-phase ultraviolet absorption cross-sections and atmospheric lifetimes of several C2-C5 alkyl nitrates. J. Photochem. Photobiol A: Chem. 102, 117-126.

de Kock, A.C., Anderson, C.R., 1994. The measurement of C3C5 alkyl nitrates at a coastal sampling site in the Southern hemisphere. Chemosphere 29, 299-310.

Derwent, R.G., Simmonds, P.G., O'Doherty, S., Ryall, D.B., 1998. The impact of the Montreal protocol on halocarbon concentrations in Northern hemisphere baseline and European air masses at Mace Head, Ireland over a ten year period from 1987-1996. Atmos. Environ. 32, 3689-3702.

Fan, S.M., Jacob, D.J., Mauzerall, J.D., Bradshaw, D., Sandholm, S.T., Blake, D., Singh, H.B., Talbot, R., Gregory, G.L., Sachse, G.W., 1994. Origin of tropospheric
$\mathrm{NO}_{x}$ over subarctic Eastern Canada in summer. J. Geophys. Res. 99, 16867-16877.

Finlayson-Pitts, B.J., Pitts Jr., J.N., 1986. Atmospheric Chemistry: Fundamentals and Experimentals Techniques. John Wiley \& Sons, New York.

Fischer, R.G., 1999. Vorkommen und Umweltverhalten der $\mathrm{C}_{1}-\mathrm{C}_{10}$ organischen Nitrate in kontinentaler und mariner Luft. Dissertation Dr. rer. nat., Universität Ulm.

Fischer, R.G., Ballschmiter, K., 2001. Global occurrence and pattern of short chain alkyl nitrates. In: Proceedings Symposium Atmospheric Reactive Compounds. Bayreuth 1999, in press.

Fischer, R.G., Kastler, J., Ballschmiter, K., 2000. Levels and pattern of alkyl nitrates, multifunctional alkyl nitrates, and halocarbons in the air over the Atlantic Ocean. J. Geophys. Res. 105, 14473-14494.

Flocke, F., Volz-Thomas, A., Buers, H.J., Pätz, H.W., Garthe, H.J., Kley, D., 1998. Long-term measurements of alkyl nitrates in Southern Germany 1. General behavior and seasonal and diurnal variation. J. Geophys. Res. 103, 57295745.

Fraser, M.P., Cass, G.R., Simoneit, B.R.T., Rasmussen, R.A., 1997. Air quality model evaluation data for organics 4. $C_{2}-$ $\mathrm{C}_{36}$ non-aromatic hydrocarbons. Environ. Sci. Technol. 31, 2356-2367.

Gaffney, J.S., Fajer, R., Senum, G.I., Lee, J.H., 1986. Measurement of the reactiviy of $\mathrm{OH}$ with methyl nitrate: implication for prediction of alkyl nitrate- $\mathrm{OH}$ reaction rates. Int. J. Chem. Kinetics 18, 399-407.

Jones, A.E., Weller, R., Minikin, A., Wolff, S., Sturges, W.T., McIntyre, M.E., Leonard, S.R., Schrems, O., Bauguitte, S., 1999. Oxidized nitrogen chemistry and speciation in the Antarctic troposphere. J. Geophys. Res. 104, 21355 21366.

Kakesu, M., Bandow, H., Takenaka, N., Maeda, Y., et al., 1997. Kinetic measurements of methyl and ethyl nitrate reactions with $\mathrm{OH}$ radicals. Int. J. Chem. Kinetics 29, 933941.

Kastler, J., 1999. Analytik, Massenspektrometrie und Vorkommen multifunktioneller Alkylnitrate in belasteter und unbelasteter Atmosphäre. Dissertation Dr. rer. nat., Universität Ulm.

Kastler, J., Ballschmiter, K., 1998. Bifunctional alkyl nitrates-trace constituents of the atmosphere. Fresenius J. Anal. Chem. 360, 812-816.

Kastler, J., Ballschmiter, K., 1999. Identification of alkyl dinitrates in ambient air of Central Europe. Fresenius J. Anal. Chem. 363, 1-4.

Köhler, J., Meyer, R., 1995. Explosivstoffe. VCH, Weinheim.

Kondo, Y., Koike, M., Kawakami, S., Singh, H.B., Nakajiama, H., Gregory, G.L., Blake, D.R., Sachse, G.W., Merrill, J.T., Newell, R.E., 1997. Profiles and partitioning of reactive nitrogen over Pacific Ocean in winter and early spring. J. Geophys. Res. 102, 28 405-28 424.

Leaitch, W.R., Barrie, L.A., Bottenheim, J.W., Li, S.M., Shepson, P.B., Muthuramu, K., Yokouchi, Y., 1994. Airborne observations related to ozone depletion at Polar Sunrise. J. Geophys. Res. 99, 25499-25 517.

Muthuramu, K., Shepson, P.B., Bottenheim, J.W., Jobson, B.T., Niki, H., Anlauf, K.G., 1994. Relationsships between organic nitrates and surface ozone destruction during Polar 
Sunrise Experiment 1992. J. Geophys. Res. 99, 25369 25378.

O’Brien, J.M., Shepson, P.B., Muthuramu, K., Hao, C., Hastie, D.R., 1995. Measurement of alkyl and multifunctional organic nitrates at a rural site in Ontario. J. Geophys. Res. 100, 22 795-22804.

O'Brien, J.M., Shepson, P.B., Wu, Q., Biesenthal, T.A., Bottenheim, J.W., Wiebe, H.A., Anlauf, K.G., Brickell, P., 1997. Production and distribution of organic nitrates, and their relationship to carbonyl compounds in an urban environment. Atmos. Environ. 31, 2059-2069.

Orlando, J.J., Tyndall, G.S., Calvert, J.G., 1992. Thermal decomposition pathways for peroxyacetyl nitrate (PAN)implications for atmospheric methyl nitrate levels. Atmos. Environ. Part A-General Topic 17, 3111-3118.

Platt, U., Le Bras, G., 1997. Influence of DMS on the $\mathrm{O}_{x}-\mathrm{NO}_{y}$ partitioning and the $\mathrm{NO}_{x}$ distribution in the marine background atmosphere. Geophys. Res. Lett. 24, 1935-1938.

Roberts, J.M., 1990. The atmospheric chemistry of organic nitrates. Atmos. Environ. 24A, 243-287.

Roberts, J.M., Bertman, S.B., Parrish, D.D., Fredrick, C., Fehsenfeld, F.C., Jobson, B.T., Niki, H., 1998. Measurement of alkyl nitrates at Chebogue Point, Nova Scotia during the 1993 North Atlantic Regional Experiment (NARE) intensive. J. Geophys. Res. 130, 13 569-13 580.

Roberts, J.M., Parrish, D.D., Norton, R.B., Bertman, S.B., Holoway, J.S., Trainer, M., Fehsenfeld, F.C., Carroll, M.A., Albercook, G.M., Wang, T., Forbes, G., 1996. Episodic removal of $\mathrm{NO}_{y}$ species from the marine boundary layer over the North Atlantic. J. Geophys. Res. 101, $28947-$ 28960.

Schneider, M., Ballschmiter, K., 1996. Separation of diastereomeric and enantiomeric alkyl-nitrates - systematic approach to chiral discrimination on cyclodextrin LIPODEX-D. Chem. Eur. J. 2, 539-544.

Schneider, M., Ballschmiter, K., 1999. C3-C14 alkyl nitrates in remote South Atlantic air. Chemosphere 38, 233-244.

Schneider, M., Deissler, A., Ballschmiter, K., 1998a. Levels and patterns of $\mathrm{C} 1-\mathrm{C} 15$ alkyl nitrates, perchloroethene, and bromoform in Californian air. ACS, Division of Environmental Chemistry Reprints of Extended Abstracts 38, 1820.

Schneider, M., Luxenhofer, O., Deissler, A., Ballschmiter, K., 1998b. $C_{1}-C_{15}$ alkyl nitrates, benzyl nitrate, and bifunctional nitrates: measurements in Californian and South
Atlantic Air and global comparison using $\mathrm{C}_{2} \mathrm{Cl}_{4}$ and $\mathrm{CHBr}_{3}$ as marker molecules. Environ. Sci. Technol. 32, 3055-3062.

Schreitmüller, J., Vigneron, M., Bacher, R., Ballschmiter, K., 1994. Pattern analysis of polychlorinated biphenyls (PCB) in Marine Air of the Atlantic Ocean. Int. J. Environ. Anal. Chem. 57, 33-52.

Seinfeld, J.H., Pandis, S.N., 1998. Atmospheric Chemistry and Physics-From Air Pollution to Climate Change. John Wiley \& Sons, New York.

Senum, G.I., Fajer, R., Gaffney, J.S., 1986. Fourier transform infrared spectroscopic study of the thermal stability of peroxyacetyl nitrate. J. Phys. Chem. 90, 152-156.

Smith, G.L., 1991. Principal component analysis. an introduction. Anal. Proc. 28, 150-151.

Talukdar, R.K., Burkholder, J.B., Hunter, M., Gilles, M.K., Roberts, J.M., Ravishankara, A.R., 1997. Atmospheric fate of several alkyl nitrates: part $2 \mathrm{UV}$ absorption cross-sections and photodissoziation quantum yields. J. Chem. Soc. Farad. Trans. 93, 2797-2805.

Trainer, M., Buhr, M.P., Curran, C.M., Fehsenfeld, F.C., Hsie, E.Y., Liu, S.C., Norton, R.B., Parrish, D.D., Williams, E.J., 1991. Observations and modeling of the reactive nitrogen photochemistry at a rural site. J. Geophys. Res. 96, 30453063.

Urhahn, T., Ballschmiter, K., 1998. Chemistry of the biosynthesis of halogenated methanes: $\mathrm{C} 1$-organohalogens as pre-industrial chemical stressors in the environment? Chemosphere 37, 1017-1032.

Walega, J.G., Ridley, B.A., Madronich, S., Grahek, F.E., Shetter, J.D., Sauvain, T.D., Hahn, J., Merill, J.T., Bodhaine, B.A., Robinson, E., 1992. Observations of peroxyacetyl nitrate, peroxypropionyl nitrate, methyl nitrate and ozone during Mauna Loa Observatory Photochemistry Experiment. J. Geophys. Res. 97, 10311-10330.

Werner, G., Kastler, J., Looser, R., Ballschmiter, K., 1999. Organic nitrates of isoprene as atmospheric compounds. Angew. Chem. Int. Ed. 38, 1634-1637.

Wiedmann, T.O., Güthner, B., Class, T., Ballschmiter, K., 1994. Global distribution of tetrachloroethene in the troposphere: measurements and modeling. Environ. Sci. Technol. 28, 2321-2329.

Woidich, S., Froescheis, O., Luxenhofer, O., Ballschmiter, K., 1999. EI and NCI-mass spectrometry of arylalkyl nitrates and their occurrence in urban air. Fresenius J. Anal. Chem. 364, 91-99. 